\title{
SISTEM INFORMASI PERPUSTAKAAN BERBASIS WEB DI SEKOLAH MENENGAH PERTAMA SWASTA SANTA THERESIA 1 TUAPUKAN KUPANG TIMUR
}

\author{
Jesuino Guterres \\ Universitas Citra Bangsa, Nusa Tenggara Timur, 85111 \\ jesuino.guteres@gmail.com
}

\begin{abstract}
ABSTRAK
Penelitian ini bertujuan membangun sistem informasi perpustakaan berbasis web menggunakan bahasa pemrograman PHP dan DBMS MySQL untuk: menciptakan sebuah sistem informasi perpustakan berbasis web. Yang dapat memberikan informasi perpustakaan yang cepat, tepat, dan akurat untuk guru, siswa, petugas perpustakaan, dan pimpinan. Jenis penelitian yang digunakan adalah penelitian R\&D (Research and Development). Pengembangan sistem infromasi perpustakaan berbasis web pada penelitian ini, menggunakan model pengembangan waterfall atau air terjun yang meliputi tahap Analisis, Design, Coding, Testing, dan Maintenance. Hasil pengujian untuk aspek functionality dengan nilai $\mathrm{X}$ lebih dari 0,5 atau mendekati 1 . Maka pengujian sistem pada aspek functionality dikatakan baik karena nilai mendekati 1 . Sedangkan untuk aspek usability dari hasil presentase pengujian dengan nilai 81,4\% masuk dalam kategori "Layak" dan memenuhi aspek usability. Berdasarkan hasil tersebut maka sistem informasi yang di hasilkan dapat mengurangi kesalahan manajemen perpustakaan dengan cara konvensional sebelumnya.
\end{abstract}

Kata kunci: Sistem Informasi, Perpustakaan, Waterfall.

\section{ABSTRACT}

This research aims to develop a web-based library information system using program language of PHP and MySQL DBMS to create a web-based library information system which can provide fast, precise, and accurate library information for teachers, students, librarians, and head master. The type of research used is $R \& D$ (Research and Development). Web-based library information systems development in this study used a waterfall development model that includes the stages of analysis, design, coding, testing, and maintenance. The test results for functionality aspects is good where an $X$ value is more than 0.5 or close to 1 , then the system testing on the functionality aspect is said good because the value is close to 1 . Whereas for the usability aspect, the percentage of testing results with a value of $81.4 \%$ included in the "Eligible" category and meet the usability aspect. Based on these results, the information system can reduce library management errors which was done by previous conventional tech.

Keywords:Iinformation System, Library, Waterfall

Jurnal Pendidikan Teknologi Informasi (JUKANTI) Volume (3) No (2) Nopember 2020 | Hal - 33- 


\section{PENDAHULUAN}

Pendidikan merupakan salah satu pilar untuk menunjang kemajuan suatu bangsa. Kegiatan belajar mengajar menjadi proses yang sangat penting dalam pengembangan dunia pendidikan saat ini. Untuk menunjang proses belajar mengajar tesebut diperlukan referensi baca yang baik berupa buku, kamus, majalah dan sumber-sumber bacaan lain.

Berdasarkan Undang-undang Nomor 20 Tahun 2003 tentang Sistem Pendidikan Nasional, Pasal 45 (1) menyatakan "setiap satuan pendidikan formal dan nonformal menyediakan sarana dan prasarana yang memenuhi keperluan pendidikan sesuai dengan intelektual, sosial, emosional, dan kejiwaan peserta didik" [1].

Perpustakaan merupakan sarana yang dibangun untuk menyimpan koleksi bukubuku atau sumber bacaan. Koleksinya diperbarui untuk mengikuti perkembangan ilmu pengetahuan. Sedangkan sistem informasi perpustakaan adalah proses komputerisasi untuk mengolah data dalam suatu perpustakaan, yang diproses melalui software tertentu seperti software pengolah database.

Hasil wawancara dengan siswa dan petugas perpustakaan, peneliti mengetahui bahwa pada Sekolah Menengah Pertama Swasta Santa Theresia 1 Tuapukan Kupang Timur, pengolahan data perpustakaannya masih dilakukan dengan cara konvensional, yaitu dengan menuliskannya ke dalam buku inventaris. Hal ini menimbulkan beberapa permasalahan yaitu; lamanya mencari buku karena tidak tersusun dengan rapi, petugas kesulitan dalam mengelola data peminjaman dan data pengembalian, karena harus selalu membuka catatan sehingga rentan terhadap kesalahan, petugas juga kesulitan memeriksa buku-buku yang semakin banyak dan beberapa buku didapati sudah rusak. Selain itu belum adanya jaringan LAN (Local Area Network) dan internet.

Oleh sebab itu perubahan bentuk pengolahan data perpustakaan yang konvensional ke pengolahan data yang berbasis komputer menjadi solusi untuk mengatasi keterlambatan informasi dan kesulitan manajemen perpustakan. Sehubungan dengan hal tersebut, maka peneliti membuat suatu sistem informasi perpustakaan berbasis web, yang dapat memberikan informasi perpustakaan yang cepat, tepat, dan akurat untuk guru, siswa, petugas perpustakaan, dan pimpinan.

\section{METODE PENELITIAN}

Metode penelitian yang digunakan adalah penelitian R\&D (Research and Development), adalah Metode penelitian yang digunakan untuk menghasilkan produk tertentu, dan menguji keefekifan produk tersebut [5]. Dengan menggunakan model pengembangan waterfall atau air terjun, merupakan metode pengembangan perangkat lunak yang secara umum dilakukan oleh para peneliti sistem, dengan melalui beberapa tahapan penelitian yaitu Analisis, Design, Coding, Testing, dan Maintenance [4]. Model pengembangan sistem Waterfall dapat dilihat sebaga berikut: 


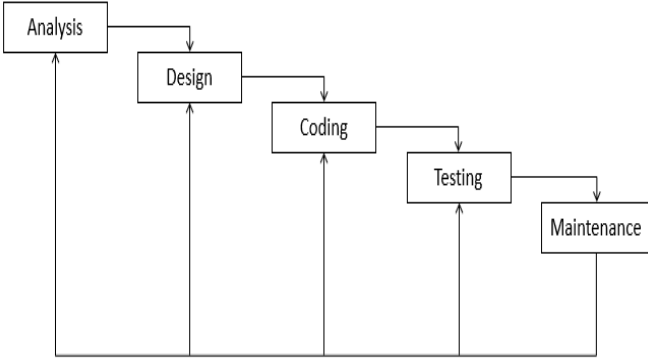

Gambar 1. Model Pengembangan Sistem

$$
\text { Waterfall }
$$

\section{Analisis}

Pada tahap ini, peneliti mengidentifikasi kebutuhan-kebutuhan yang diperlukan dalam merancang sistem informasi perpustakaan berbasis web misalnya data buku pada perpustakaan SMP Swasta Santa Theresia 1 Tuapukan Kupang Timur.

\section{Desain (Design)}

Tahap design merupakan proses menjelaskan dengan detail bagaimana bagian-bagian dari sistem informasi diimplementasikan [2]. Pada tahap ini akan meliputi design sistem, design basis data, dan design interface sebagai berikut:

\section{a. Desain Sistem}

Desain sistem merupakan gambaran dari analisis kebutuhan yang ada. Untuk menggambarkan alur dari sistem yang akan dibuat, peneliti menggunakan DFD Fisik (Data Flow Diagram). DFD Fisik adalah representasi grafik dari sebuah sistem yang menunjukkan entitas-entitas internal dan eksternal dari sistem tersebut, dan aliranaliran data ke dalam dan keluar dari entitasentitas tersebut [3]. Berikut merupakan design sistem informasi perpustakaan berbasis web di SMP Swasta Santa Theresia 1 Tuapukan Kupang Timur.

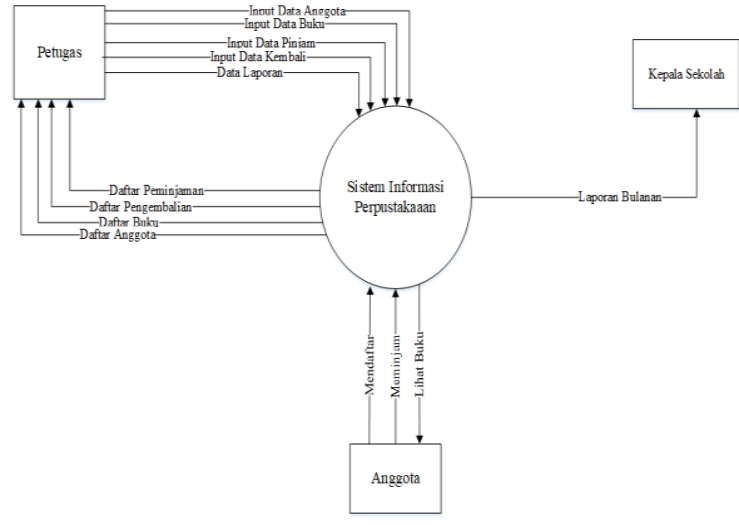

Gambar 2. Conteks Diagram

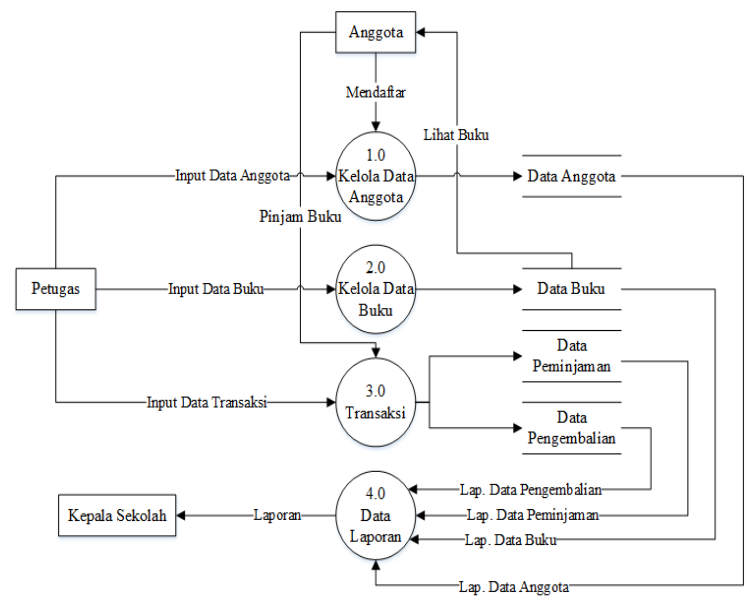

Gambar 3. DFD Level 0

\section{b. Desain Basis Data}

Basis data disini digunakan untuk menyimpan data yang dimasukkan ke dalam sistem dan data yang akan ditampilkan pada sistem. Basis data ini disesuaikan dengan kebutuhan sistem. Untuk menggabarkan alur dari basis data yang berjalan pada sistem, peneliti akan menggunakan ERD (Entity Relationship Diagram). Berikut merupakan design basis data perpustakaan berbasis web di SMP Swasta Santa Theresia 1 Tuapukan Kupang Timur. 


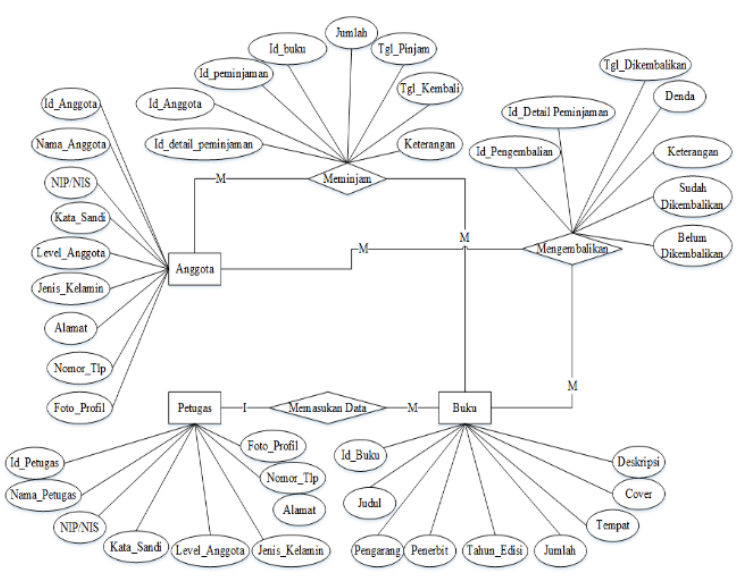

Gambar 4. ERD (Entity Relationship Diagram)

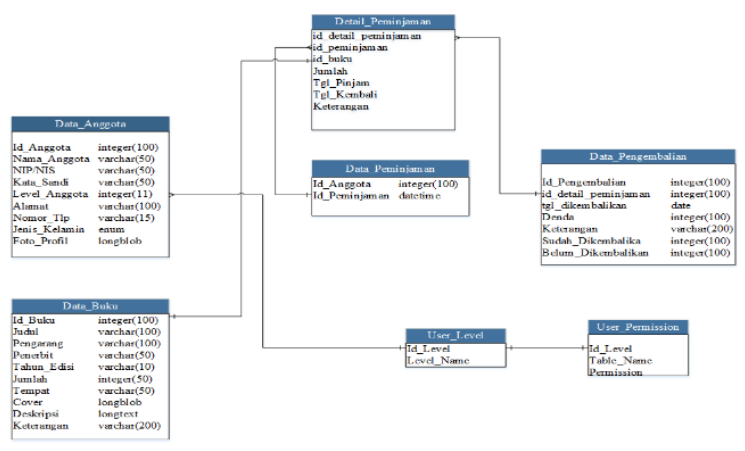

Gambar 5. Relasi Tabel

c. Desain Antarmuka (Design Interface)

Design interface merupakan rancangan antarmuka untuk menggambarkan tampilan dari sistem yang akan dibangun agar mudah dipahami oleh pengguna. Berikut merupakan design interface sistem informasi perpustakaan berbasis web di SMP Swasta Santa Theresia 1 Tuapukan Kupang Timur.

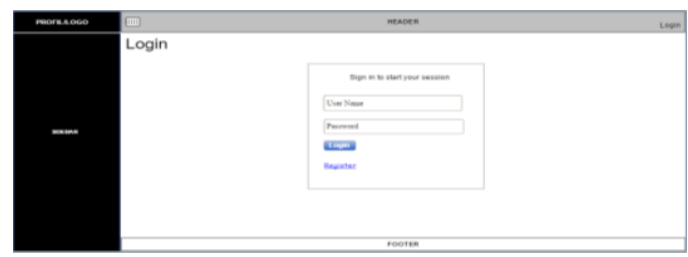

Gambar 6. Halaman Login

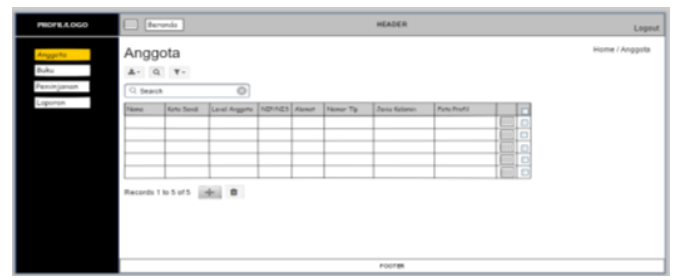

Gambar 7. Halaman Petugas - menu anggota

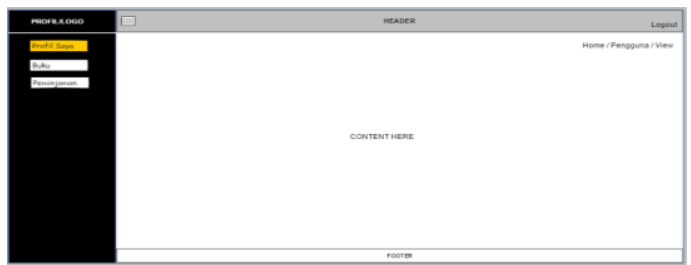

Gambar 8. Halaman Anggota - menu profil saya

\section{Coding}

Pada tahap ini peneliti mengaplikasikan desain yang telah dirancang ke dalam bahasa pemrograman. Software yang digunakan adalah dengan menggunakan bahasa pemrograman PHP serta MySQL sebagai databasenya.

\section{Testing}

Tahap ini merupakan pengujian sistem secara keseluruhan. Pada penenlitian ini peneliti akan melakukan tahap pengujian dengan menggunakan metode black box untuk mengukur aspek functionality dan usability.

\section{Maintenance}

Tahap ini merupakan tahapan penggunaan sistem oleh user yang didalamnya harus ada pemeliharaan sistem untuk menjaga proses operasional sistem dan memungkinkan untuk dilakukan pengembangan sistem di kemudian hari (Saputra, 2012) [4]. 


\section{HASIL DAN PEMBAHASAN}

Halaman Login, pada halaman login didalamnya berisikan user name, password, register dan fungsi login.

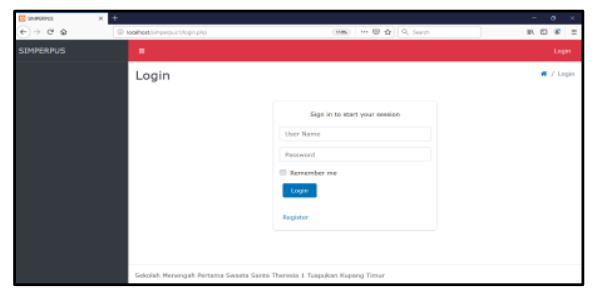

Gambar 14. Tampilan Halaman Login.

Halaman petugas - menu anggota, pada menu anggot didalamnya berisikan data pengguna dengan beberapa field seperti nama, NIP, NIS, kata sandi, level anggot, alamat, nomor tlp, jenis kelamin dan foto profil. Pada menu anggot terdapat beberapa fungsi yakni add, view, search, edit, delete dan filters.

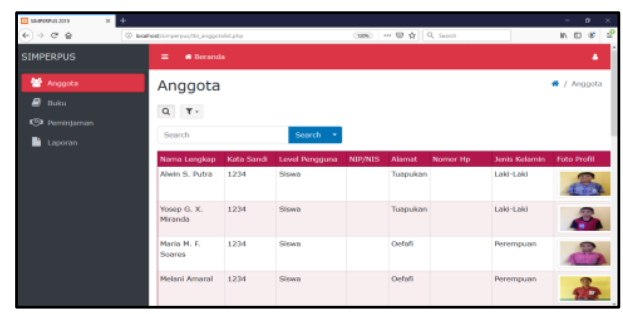

Gambar 15. Tampilan Halaman Petugas menu anggota

Tampilan halaman anggota - menu profil saya, pada menu profil saya berisikan sebuah informasi tentang data diri pengguna.

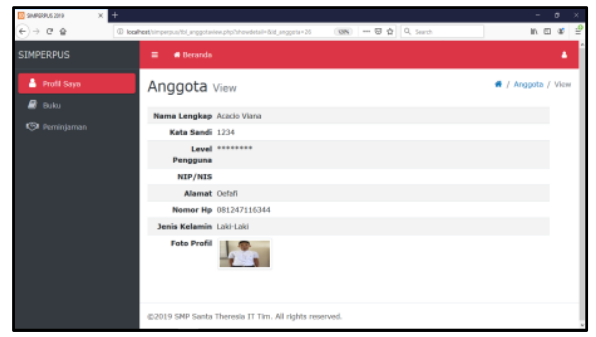

Gambar 16. Tampilan Halaman Anggota menu profil saya

\section{Testing}

\section{Pengujan Aspek Fuctionality}

Pengujian functionality dilakukan oleh 1 petugas perpustakaan dan 2 ahli media dengan menggunakan kuesioner yang telah disediakan peneliti, yang berisi beberapa daftar fungsi pada sistem informasi.

$\mathrm{X}=1-\frac{A}{B}$

Keterangan

$\mathrm{X}=$ Functionalty

$\mathrm{A}=$ Jumlah total fungsi yang tidak valid

$\mathrm{B}=$ Jumlah seluruh fungsi

Presentasi untuk masing-masing penilaian adalah sebagai berikut:

Ya : 33

Tidak : 12

Setelah melakukan perhitungan maka didapat hasil sebagai berikut.

$\mathrm{X}=1-\frac{12}{45}$

$X=1-0,266$

$X=0,733$

Berdasarkan rumus pengukuran implementasi functionality tersebut, dengan nilai $\mathrm{X}$ lebih dari 0,5 atau mendekati 1 . Maka pengujian sistem pada aspek functionality dikatakan baik karena nilai mendekati 1.

\section{Pengujian Aspek Usability}

Pengujian usability dilakukan oleh 30 responden yang terdiri dari guru, petugas perpustakaan dan siswa dengan jumlah pertanyaan 19 buah. Hasil dari pengujian usability dapat dilihat pada tabel dibawah ini: 
Tabel 1. Perhitungan Skor Total Pengujian Usability

\begin{tabular}{|c|c|c|c|}
\hline & Jumlah & Skor & Hasil \\
\hline SS & 196 & 5 & 980 \\
\hline S & 260 & 4 & 1040 \\
\hline RG & 85 & 3 & 255 \\
\hline TS & 21 & 2 & 42 \\
\hline STS & 5 & 1 & 5 \\
\hline \multicolumn{3}{|c|}{ Skor Total } & $\mathbf{2 3 2 2}$ \\
\hline
\end{tabular}

Skor total yang telah didapat kemudian dihitung untuk menentukan kualitas. Berikut penyelesaian akhir untuk pengujian usability.

$$
\begin{aligned}
\text { Index }(\%) & =\frac{\text { Jumlah Skor Total }}{\text { Nilai Tertinggi }} \times 100 \\
& =\frac{2322}{30 \times 5 \times 19} \times 100 \\
& =\frac{2322}{2850} \times 100 \\
& =81,4 \%
\end{aligned}
$$

Untuk menentukan kualitas menggunakan tabel kategori yang telah dibuat sebelumnya. Untuk kategori penilaian dapat dilihat pada tabel dibawah ini :

Tabel 2. Kategori Penilaian Faktor Kualitas Usability

\begin{tabular}{|c|c|}
\hline Interval & Kategori \\
\hline $84 \%-100 \%$ & Sangat Layak \\
\hline $68 \%-83,99 \%$ & Layak \\
\hline $52 \%-67,99 \%$ & Cukup Layak \\
\hline $36 \%-51,99 \%$ & Tidak Layak \\
\hline $20 \%-35,99 \%$ & Sangat Tidak Layak \\
\hline
\end{tabular}

Berdasarkan tabel diatas maka hasil presentase pengujian dengan nilai 81,4\% masuk dalam kategori "Layak" dan memenuhi aspek usability.

\section{KESIMPULAN}

Sistem Informasi perpustakaan berbasis web di SMP Swasta Santa Theresia
1 Tuapukan Kupang Timur dikembangkan menggunakan model waterfall yang terdiri dari lima tahap, (1) Analisis; (2) Design; (3) Coding; (4) Testing; dan (5) Maintenance. Sistem ini di buat menggunakan bahasa pemograman PHP dan DBMS MySQL. Yang memiliki fitur untuk manajemen perpustakaan seperti kelola pengguna, kelola buku, kelola peminjaman, kelola pengembalian dan laporan. Hasil pengujian untuk aspek functionality dengan nilai $\mathrm{X}$ lebih dari 0,5 atau mendekati 1. Maka pengujian sistem pada aspek functionality dikatakan baik karena nilai mendekati 1 . Sedangkan untuk aspek usability dari hasil presentase pengujian dengan nilai $81,4 \%$ masuk dalam kategori "Layak" dan memenuhi aspek usability. Berdasarkan hasil tersebut maka sistem informasi yang di hasilkan dapat mengurangi kesalahan manajemen perpustakaan dengan cara konvensional sebelumnya.

\section{DAFTAR PUSTAKA}

[1] Darmono. Perpustakan Sekolah. Jakarta: Grasindo. 2007.

[2] Fatta, A.H. (2007). Analisis \& Perancangan Sistem Informasi. Yogyakarta: Andi. 2007.

[3] Ranatarisza, M.M. \& Noor, A.M. Sistem Informasi Akuntansi Pada Aplikasi Administrasi Bisnis. Malang: UB Press. 2013.

[4] Saputra, A. Sistem Informasi Nilai Akademik Untuk Panduan Skripsi. Jakarta: PT Elex Media Komputindo. 2012.

[5] Sugiyono. Metode Penelitian Pendidikan. Bandung: Alfabeta. 2016. 